\title{
Gold-loaded nanoporous ferric oxide nanocubes for electrocatalytic detection of microRNA at attomolar level
}

Md. Nazmul Islam, ${ }^{\mathrm{a}, \mathrm{b}}$, Mostafa Kamal Masud ${ }^{\mathrm{b}, \mathrm{c}}$, Nam-Trung Nguyen ${ }^{\mathrm{b}}$, Vinod Gopalan ${ }^{\mathrm{d}}$, Hatem R. Alamri, ${ }^{\mathrm{e}}$ Zeid A. Alothman, ${ }^{\mathrm{f}}$ Md. Shahriar Al Hossain ${ }^{\mathrm{c}, \mathrm{g}}$, Yusuke Yamauchi ${ }^{\mathrm{c}, \mathrm{g}, \mathrm{h}}$, Alfred K. Lam ${ }^{\text {d }}$, Muhammad J. A. Shiddiky ${ }^{\mathrm{a}, \mathrm{b}, *}$

${ }^{\text {a }}$ School of Natural Sciences, Griffith University, Nathan Campus, QLD 4111, Australia.

${ }^{\mathrm{b}}$ Queensland Micro- and Nanotechnology Centre, Griffith University, Nathan Campus, QLD 4111, Australia.

cAustralian Institute for Innovative Materials (AIIM), University of Wollongong, Squires Way, Innovation Campus, North Wollongong, NSW 2500, Australia.

${ }^{\mathrm{d}}$ Cancer Molecular Pathology Laboratory in School of Medicine, Menzies Health Institute Queensland, Griffith University, Gold Coast Campus, QLD 4222, Australia

e Physics Department, Jamoum University College, Umm Al-Qura University, Makkah, 21955, Saudi Arabia

${ }^{\mathrm{f}}$ Advanced Materials Research Chair, Chemistry Department, College of Science, King Saud University, Riyadh 11451, Saudi Arabia

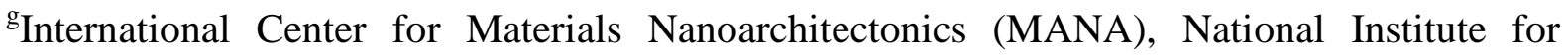
Materials Science (NIMS), 1-1 Namiki, Tsukuba, Ibaraki 305-0044, Japan

${ }^{\mathrm{h}}$ School of Chemical Engineering \& Australian Institute for Bioengineering and Nanotechnology (AIBN), The University of Queensland, Brisbane, QLD 4072, Australia *Corresponding author E-mail address: m.shiddiky@griffith.edu.au (M.J.A.S) 


\section{ABSTRACT}

A crucial issue in microRNA (miRNA) detection is the lack of sensitive method capable of detecting the low levels of miRNA in RNA samples. Herein, we present a sensitive and specific method for the electrocatalytic detection of miR-107 using gold-loaded nanoporous superparamagnetic iron oxide nanocubes ( $\left.\mathrm{Au}-\mathrm{NPFe}_{2} \mathrm{O}_{3} \mathrm{NC}\right)$. The target miRNA was directly adsorbed onto the gold surfaces of $\mathrm{Au}-\mathrm{NPFe}_{2} \mathrm{O}_{3} \mathrm{NC}$ via gold-RNA affinity interaction. The electrocatalytic activity of $\mathrm{Au}-\mathrm{NPFe}_{2} \mathrm{O}_{3} \mathrm{NC}$ was then used for the reduction of ruthenium hexaammine(III) chloride (RuHex, $\left[\mathrm{Ru}\left(\mathrm{NH}_{3}\right)_{6}\right]^{3+}$ ) bound with target miRNA. The catalytic signal was further amplified by using the ferri/ferrocyanide $\left[\mathrm{Fe}(\mathrm{CN})_{6}\right]^{3-/ 4-}$ system. These multiple signal enhancement steps enable our assay to achieve the detection limit of $100 \mathrm{aM}$ which is several orders of magnitudes better than most of the conventional miRNA sensors. The method was also successfully applied to detect miR-107 from cancer cell lines and a panel of tissue samples derived from patients with oesophageal squamous cell carcinoma with excellent reproducibility (\% RSD $=<5 \%$, for $n=3$ ) and high specificity. The analytical accuracy of the method was validated with a standard RT-qPCR method. We believe that our method has the high translational potential for screening miRNAs in clinical samples.

\section{Keywords:}

microRNA detection, electrochemical detection, nanoporous iron oxide, electrocatalysis, oesophageal cancer, screen-printed electrodes 


\section{Introduction}

MicroRNAs (miRNAs) are short (approximately 19-23 nucleotides) and endogenous noncoding RNAs that control a range of cellular processes including post-transcriptional gene expression and epigenetic remodelling (Dong et al., 2013). The emerging functional insights of miRNAs and their promising role as the biomarker for various diseases including cancer have triggered extensive development of miRNA detection technologies (Dong et al., 2013; Hayes et al., 2014; Islam et al., 2017). Despite these developments, the miRNA detection technologies have yet to achieve their translation into routine clinical applications, partly due to the lack of sensitive and specific analysis methods (Islam et al., 2017). It is important to note that the abundance of miRNA in clinical samples is typically at the $0.2 \mathrm{fM}$ to $20 \mathrm{pM}$ level (Dong et al., 2013; Johnson and Mutharasan, 2014). Moreover, structure and size homology of closely-related non-target RNAs present in the clinical samples pose significant challenges in their specific detection (Labib et al., 2016). The detection method therefore needs to be highly sensitive as well as specific with negligible non-specific background response.

A few nucleic acid detection methods; namely microarrays, RNA-sequencing (RNAseq) and real time quantitative polymerase chain reaction (RT-qPCR) have been developed for the investigation of RNA (Mestdagh et al., 2014). However, due to the size match of miRNA and standard PCR primers, most of these methods cannot efficiently amplify the target miRNAs (Pritchard et al., 2012). To overcome this, enzymatic elongation of the template miRNA (e.g., polyadenylation) and specially designed primers (e.g., oligo dT or stem-loop primers) have been used. Additionally, RT-qPCR has the limitation for the 
absolute quantification of miRNAs since it analyses miRNA expression with an internal standard (Islam et al., 2017). Among other amplification-based strategies, the high throughput microarray and RNA-seq methods are best suited for discovery and validation of novel miRNA biomarkers rather than diagnostic applications. Moreover, all these methods largely depend on sophisticated and costly laboratory instrument, which is not suitable for the miRNA biomarker screening in resource-limited settings.

In recent years, increasing interest in the simple, miniaturized and cost-effective analysis of biomarkers has led to the development of many electrochemical strategies which generally rely on capture probe-based hybridization or sandwich assay formats (Fang et al., 2017; Labib and Berezovski, 2015). However, these electrochemical assays may not meet the requirement of ultrasensitive miRNA detection in clinical samples, mainly due to the lack of appropriate signal enhancement ability. It has been widely reported that one of the effective ways to increase the sensitivity of electrochemical assays is the use of nanomaterial-based signal amplification strategies. Nanomaterials have the inherent advantages of high catalytic properties, biomimetic activity, biocompatibility, excellent conductivity and high sample loading capacity (Dong et al., 2013; Xia et al., 2015). Therefore, nanomaterials have widely been used in electrochemical sensors as the tracers, catalysts and electronic conductors to improve the sensitivity of miRNA detection (Dong et al., 2013; Peng et al., 2014; Xia et al., 2013). For example, Gao and Yang (2006) used isoniazid-capped $\mathrm{OsO}_{2}$ nanoparticles for labelling RNA molecules to electrocatalytically amplify the detection signal. Recently, composite nanomaterials, such as bimetallic hybrid nanomaterials (e.g., $\mathrm{Fe}_{2} \mathrm{O}_{3} @ \mathrm{Ag}$ ), have also been used for amplifying electrocatalytic signal in detecting miRNA (Pang et al., 2016). Very recently, we designed and synthesized a new class of gold-loaded ferric oxide nanocubes (Au-NPFe${ }_{2} \mathrm{O}_{3} \mathrm{NC}$ ) (Yadav et al., 2017) that exhibit several functionalities. These includes (i) superparamagnetic - the nanocubes are paramagnetic and thus highly suitable for 
magnetic isolation and separation; (ii) electrocatalyst - the nanocubes possess high electrocatalytic activity (Masud et al., 2017) towards many common electroactive materials such as ruthenium hexaammine(III) chloride (RuHex, $\left[\mathrm{Ru}\left(\mathrm{NH}_{3}\right)_{6}\right]^{3+}$ ), and (iii) enhanced loading capacity - the exposed gold surfaces of the highly porous $\mathrm{Au}-\mathrm{NPFe}_{2} \mathrm{O}_{3} \mathrm{NC}$ can be used to adsorb large amount of target nucleotide sequences via DNA/RNA- gold affinity interaction (Islam et al., 2017b; Koo et al., 2016a, b; Koo et al., 2015; Sina et al., 2014a; Sina et al., 2014b).

The increasing demand for detecting the ultralow levels of miRNAs with electrochemical techniques has also resulted in the integration of more than one signal amplification step in a single assay platform (Fang et al., 2017; Liu et al., 2014). In particular, the nanoparticle-mediated electrocatalysis can be coupled with one or more electrocatalytic cycles to obtain enhanced sensitivity (Zhang et al., 2006). In such electrocatalytic assays, one redox molecule is first electrochemically oxidized or reduced at the electrode surface upon hybridization/intercalation with the target sequence (Zhang et al., 2007). This reaction is then coupled to another redox molecule that regenerates the oxidized or reduced species back to its original state. The resultant sharp increase in the electron flux produces an enhanced electrochemical signal. For example, Barton and Kelley groups have reported a series of studies to detect different DNA-based biomarkers where electroactive methylene blue (MB) or RuHex were coupled to ferri/ferrocyanide $\left(\left[\mathrm{Fe}(\mathrm{CN})_{6}\right]^{3-/ 4-}\right)$ to obtain the amplified electrocatalytic signal (Boon et al., 2000; Kelley et al., 1999; Lapierre et al., 2003).

In this paper, leveraging the benefits of superparamagnetic, high eletrocatalytic activity and surface loading capacity of highly porous framework of $\mathrm{Au}-\mathrm{NPFe}_{2} \mathrm{O}_{3} \mathrm{NC}$ and portability of disposable screen-printed carbon electrode (SPCE), we develop an miRNA detection method which pushed the detection limit down to attomolar levels $(\mathrm{LOD}=100$ aM). It has been reported that, conventional gold disk electrodes often exhibit excess 
background currents due to their high electrocalaytic properties and capacitive charges (Park et al., 2014). Moreover, due to multiple surface reactions on these conventional electrodes, tedious cleaning procedures are required for their full functionality. On the contrary, our assay uses single-use (i.e., disposable) and relatively inexpensive SPCE as a platform to load the magnetically bound nanocubes, which avoids this time-consuming cleaning procedure thereby reducing the assay time and simplifying the protocol. Moreover, SPCE is portable (three-electrode systems is printed on a plastic or ceramic substrates) and has minimal sample requirement which illustrates their potential scope towards the development of miniaturized analytical device suitable for on-site application. In this assay, streptavidin-functionalised dyanabeads were first modified with a biotinylated capture probe. Then, they are dispersed in RNA sample population to isolate and purify the target miRNA. Afterwards, the isolated target miRNA was directly adsorbed on the $\mathrm{Au}-\mathrm{NPFe}_{2} \mathrm{O}_{3} \mathrm{NC}$ (via RNA-gold affinity interaction) which was magnetically immobilized on a SPCE. The detection was then achieved by chronocoulometric (CC) charge measurement of surface bound cationic $\left[\mathrm{Ru}\left(\mathrm{NH}_{3}\right)_{6}\right]^{3+}$ which was electrostatically attached with the anionic phosphate backbone of the adsorbed target miRNA. The signal was further amplified by coupling the reduction of $\left[\mathrm{Ru}\left(\mathrm{NH}_{3}\right)_{6}\right]^{3+}$ with the $\left[\mathrm{Fe}(\mathrm{CN})_{6}\right]^{3-/ 4}$ system (i.e., $\left[\mathrm{Ru}\left(\mathrm{NH}_{3}\right)_{6}\right]^{3+} /\left[\mathrm{Fe}(\mathrm{CN})_{6}\right]^{3-}$ system). We have selected miR-107 as a model target in this assay, which has diagnostic and prognostic roles in many cancers including oesophageal squamous cell carcinoma (ESCC) (Patnaik et al., 2010; Sharma et al., 2013). The clinical applicability of the assay was successfully tested in a panel of eight tissue samples derived from patients with ESCC. The data were validated with a standard RT-qPCR method.

\section{Experimental sections}

\subsection{Isolation of Target miRNA}


ESCC cell lines (HKESC-1 and HKESC-4) were grown and maintained according to the previouly described procedures (Cheung et al., 2007; Hu et al., 2000). The RNA samples from four matched fresh ESCC and non-neoplastic tissues were used for this study (Haque et al., 2017). Total RNA was extracted and purified from the cell lines and tissue samples according to manufacturer's guidelines (Qiagen, Germany). Target miRNA was captured via dynabead-based miRNA separation procedures with a slight modification of our previous report (Koo et al., 2016b). Briefly, target miRNA were hybridized onto complementary capture probes functionalized magnetic beads (The list oligonucleotide sequences are provided in Table S1). Then, hybridized targets were magnetically purified, heat-released, and resuspended in RNase-free water. (See supplementary materials for more details)

\subsection{Electrochemical Detection of miRNA}

In this study, we utilized Au-NPFe ${ }_{2} \mathrm{O}_{3} \mathrm{NC}$ to modify SPCE (SEM images of the bare and modified SPCE are provided in Fig. S1, where the bio-favourable physicochemical properties of AuNPs (i.e. affinity interaction of DNA/RNA with gold) was exploited to capture target miRNAs. Briefly, SPCE was rinsed with an excess amount of Milli-Q water before the adsorption of miRNA. To attach Au-NPFe $\mathrm{O}_{3} \mathrm{NC}$ to the SPCE surface, the electrode was placed on a permanent magnet and $4.0 \mu \mathrm{g}$ of $\mathrm{Au}-\mathrm{NPFe}_{2} \mathrm{O}_{3} \mathrm{NC}$ was put and incubated onto the electrode surface for $45 \mathrm{~min}$. The electrode was then washed with $10 \mathrm{mM}$ PBS to remove any unattached or loosely attached particles from the electrode surface. The effective areas of SPCE was determined by using the Randles -Sevcik equation (See Eqn. S1 in supplementary materials) as shown before (Shiddiky et al., 2010; Shiddiky et al., 2009). Fig. S2 shows the typical cyclic voltammogram of bare and modified electrodes. Using CC, the amount of miRNA adsorbed onto the $\mathrm{Au}-\mathrm{NPFe}_{2} \mathrm{O}_{3} \mathrm{NC} / \mathrm{SPCE}$ surface was calculated from the number of cationic RuHex electrostatically bound with the surface-attached anionic 
phosphate backbone of miRNA following the integrated Cottrell Eqn (Steel et al., 1998).(See supplementary materials for detailed experimental)

\section{Results and discussion}

\subsection{Detection Principle}

The principle of our assay is schematically illustrated in Fig. 1. The assay is comprised of three main steps including (i) magnetic separation and purification of target miR-107, (ii) direct adsorption of target RNA on the $\mathrm{Au}-\mathrm{NPFe}_{2} \mathrm{O}_{3} \mathrm{NC}$, and (iii) CC readout via $\left[\mathrm{Ru}\left(\mathrm{NH}_{3}\right)_{6}\right]^{3+} /\left[\mathrm{Fe}(\mathrm{CN})_{6}\right]^{3-}$ system based electrocatalytic signal amplification. Briefly, total RNA extracted from de-identified ESCC tissue were initially incubated with the miR-107 specific biotinylated capture probe. Upon hybridization of the capture probe with miR-107, streptavidin-labelled dynabeads were dispersed into the reaction mixture which attached with the biotinylated capture probe-target duplex. In this assay, commercially available streptavidin-coated dynabeads are functionalised with biotinylated capture probe and used for the magnetic isolation and purification of target miRNAs from the RNA sample pool. The complex was then magnetically isolated using dynabead-based standard protocol. After heating at $95{ }^{\circ} \mathrm{C}$, the released (target) miRNA was isolated by another magnetic separation step (See Experimental Section for details) and directly adsorbed onto the $\mathrm{Au}-\mathrm{NPFe}_{2} \mathrm{O}_{3} \mathrm{NC}$ modified screen-printed carbon electrode (SPCE/Au-NPFe $\mathrm{O}_{3} \mathrm{NC}$ ). The direct adsorption of RNA on the gold surface was facilitated by RNA-gold affinity interaction phenomenon which was demonstrated earlier (Islam et al., 2017b; Koo et al., 2016a, b). The target miR-107 were then detected by the CC charge interrogation in the presence of the surface bound $\left[\mathrm{Ru}\left(\mathrm{NH}_{3}\right)_{6}\right]^{3+}$ where positively charged $\left[\mathrm{Ru}\left(\mathrm{NH}_{3}\right)_{6}\right]^{3+}$ binds to the anionic phosphate backbone of miR-107 adsorbed on the SPCE/Au-NPFe ${ }_{2} \mathrm{O}_{3} \mathrm{NC}$ surfaces. 
To further amplify the electrochemical signal, $\left[\mathrm{Ru}\left(\mathrm{NH}_{3}\right)_{6}\right]^{3+}$ system was coupled to $\left[\mathrm{Fe}(\mathrm{CN})_{6}\right]^{3-}$ where the electrocatalytic reduction of $\left[\mathrm{Ru}\left(\mathrm{NH}_{3}\right)_{6}\right]^{3+}$ further reduces the solutionphase $\left[\mathrm{Fe}(\mathrm{CN})_{6}\right]^{3-}$. Because $\left[\mathrm{Fe}(\mathrm{CN})_{6}\right]^{3-}$ in the solution (i.e., diffusion layer) is relatively stronger oxidant, it oxidized $\left[\mathrm{Ru}\left(\mathrm{NH}_{3}\right)_{6}\right]^{2+}$ for the regeneration of $\left[\mathrm{Ru}\left(\mathrm{NH}_{3}\right)_{6}\right]^{3+}$ (i.e., initiation of the electrocatalytic cycle ). Thus, the electrocatalytic cycle reported here follows an electron transfer kinetic-based mechanism which can be described by the following Eqn.1 and 2 (Zhang et al., 2007).

$$
\begin{aligned}
& {\left[R u\left(N_{3}\right)_{6}\right]^{3+}+e^{-} \rightarrow\left[R u\left(N H_{3}\right)_{6}\right]^{2+} \ldots \quad \ldots \quad \ldots \quad \ldots} \\
& {\left[\mathrm{Ru}\left(\mathrm{NH}_{3}\right)_{6}\right]^{2+}+\left[\mathrm{Fe}(\mathrm{CN})_{6}\right]^{3-} \rightarrow\left[\mathrm{Ru}\left(\mathrm{NH}_{3}\right)_{6}\right]^{3+}+\left[\mathrm{Fe}(\mathrm{CN})_{6}\right]^{4-} \ldots \quad \ldots \quad \ldots \quad \ldots}
\end{aligned}
$$

In this assay, the enhanced electrocatalytic signal (i.e., CC charge) generated by the $\left[\mathrm{Ru}\left(\mathrm{NH}_{3}\right)_{6}\right]^{3+} /\left[\mathrm{Fe}(\mathrm{CN})_{6}\right]^{3-}$ system after miRNA binding onto the surface of SPCE/Au$\mathrm{NPFe}_{2} \mathrm{O}_{3} \mathrm{NC}$ should have a clear correlation with the concentration of target miRNA.

\subsection{Electrocatalytic Activity of $\mathrm{Au}-\mathrm{NPFe}_{2} \mathrm{O}_{3} \mathrm{NC}$ and Signal Enhancement}

To check the effect of the composition of nanomaterials on the electrocatalytic activity and signal enhancement of our assay, we modified SPCE with $\mathrm{NPFe}_{2} \mathrm{O}_{3} \mathrm{NC}$ (nanoporous iron oxide nanocubes without AuNPs) and $\mathrm{Au}-\mathrm{NPFe}_{2} \mathrm{O}_{3} \mathrm{NC}$ and compared the assay performance for detecting miR-107 from 10 pM of synthetic RNA sample. As can be seen in Fig. 2 (left bar) and Fig. S3 (left bar, in supplementary materials), the total charge density (total charge $Q$ represents the Faradaic and non-Faradaic charges) obtained with the $\mathrm{SPCE} / \mathrm{NPFe}_{2} \mathrm{O}_{3} \mathrm{NC}$ and $\mathrm{SPCE} /$ bare electrodes were found to be 4.5 and $1.8 \mu \mathrm{Ccm}^{-2}$ respectively. The low level response for the SPCE/bare electrode could be responsible for the non-Faradaic component of the CC charge at the bare electrode. A slight increase of the CC 
charge (1.8 versus $4.5 \mu \mathrm{Ccm}^{-2}$ ) at the SPCE/NPFe ${ }_{2} \mathrm{O}_{3} \mathrm{NC}$-modified electrode could be related to both the Faradaic and non-Faradaic component of the charges. This may be related to the fact that a low amount of redox active $\left[\mathrm{Ru}\left(\mathrm{NH}_{3}\right)_{6}\right]^{3+}$ could be adsorbed on the $\mathrm{NPFe}_{2} \mathrm{O}_{3} \mathrm{NC}$, leading to the Faradaic component of the charges. When the electrode was modified with Au$\mathrm{NPFe}_{2} \mathrm{O}_{3} \mathrm{NC}$ (i.e., SPCE/Au-NPFe $\mathrm{O}_{3} \mathrm{NC}$ ), the total charge density significantly increased for the $\left[\mathrm{Ru}\left(\mathrm{NH}_{3}\right)_{6}\right]^{3+}$ system compared to that obtained with the SPCE/bare ( 11-fold higher, 20 versus $1.8 \mu \mathrm{Ccm}^{-2}$ ) or SPCE/ $\mathrm{NPFe}_{2} \mathrm{O}_{3} \mathrm{NC}$-modified electrodes ( 4.5 times higher, 20 versus 4.5 $\mu \mathrm{Ccm}^{-2}$ ). The enhancement of the charge response for the SPCE/Au- $\mathrm{NPFe}_{2} \mathrm{O}_{3} \mathrm{NC}$ electrode could be explained by considering these two facts (i) large surface loading capacity of highly porous framework of $\mathrm{Au}-\mathrm{NPFe}_{2} \mathrm{O}_{3} \mathrm{NC}$ and (ii) the intrinsic electrocatalytic activity of $\mathrm{Au}-\mathrm{NPFe}_{2} \mathrm{O}_{3} \mathrm{NC}$ towards the reduction of $\left[\mathrm{Ru}\left(\mathrm{NH}_{3}\right)_{6}\right]^{3+}$. The target miR-107 was directly adsorbed onto the exposed gold surfaces of the $\mathrm{Au}-\mathrm{NPFe}_{2} \mathrm{O}_{3} \mathrm{NC}$ via RNA-gold affinity interaction, which follows conventional physisorption and chemisorption mechanism. The surface-bound miR-107 (negatively charged) binds with $\left[\mathrm{Ru}\left(\mathrm{NH}_{3}\right)_{6}\right]^{3+}$ and thereby generating a higher CC charge (due to the larger contribution from Faradaic component). Recently, we have demonstrated the electrocatalytic activity of $\mathrm{Au}-\mathrm{NPFe}_{2} \mathrm{O}_{3} \mathrm{NC}$ toward the reduction of $\left[\mathrm{Ru}\left(\mathrm{NH}_{3}\right)_{6}\right]^{3+}$, where the Au-NPFe${ }_{2} \mathrm{O}_{3} \mathrm{NC}$-modified glassy carbon electrode (GCE) offered significantly enhanced cathodic $\left(i_{\mathrm{pc}}\right)$, and anodic $\left(i_{\mathrm{pa}}\right)$ peak currents for the $\left[\mathrm{Ru}\left(\mathrm{NH}_{3}\right)_{6}\right]^{3+/ 2+}$ system when compared to that of the unmodified-GCE electrode (Figs. S4 and S5 in the supplementary materials). We have also shown that the electrocatalytic activity of Au$\mathrm{NPFe}_{2} \mathrm{O}_{3} \mathrm{NC}$ follows typical Michaelis-Menten behaviour as well as Lineweaver-Burk Model for electrocatalysis (Masud et al., 2017). As our assay design requires both gold-RNA affinity interaction for adsorbing target miRNA and electrocatalysis for signal enhancement, we synthesised highly porous $\mathrm{Fe}_{2} \mathrm{O}_{3}$, which favors the controlled-loading of $2 \%$ AuNPs to achieve $\mathrm{Au}-\mathrm{NPFe}_{2} \mathrm{O}_{3} \mathrm{NC}$. 
To further enhance the catalytic signal, we coupled $\left[\mathrm{Fe}(\mathrm{CN})_{6}\right]^{3-/ 4-}$ system with the $\left[\mathrm{Ru}\left(\mathrm{NH}_{3}\right)_{6}\right]^{3+/ 4+}$. As can be seen in Fig. 2 (right bar), a 4-fold increase in the CC response was obtained compared to that of the $\left[\mathrm{Ru}\left(\mathrm{NH}_{3}\right)_{6}\right]^{3+}$ system $\left(20\right.$ versus $\left.82 \mu \mathrm{Ccm}^{-2}\right)$ at the SPCE/Au-NPFe $\mathrm{O}_{3} \mathrm{NC}$ electrode. This response is also 18 times higher compared to that of the $\mathrm{SPCE} / \mathrm{NPFe}_{2} \mathrm{O}_{3} \mathrm{NC}$ - modified electrode ( 82 versus $4.5 \mu \mathrm{Ccm}^{-2}$ ), demonstrating the catalytic signal amplification for detecting miR-107 at the SPCE/Au-NPFe $\mathrm{O}_{3} \mathrm{NC}$ electrode. We assume that apart from the large surface loading capacity and electrocatalytic activity of Au-NPFe ${ }_{2} \mathrm{O}_{3} \mathrm{NC}$ (towards the $\left[\mathrm{Ru}\left(\mathrm{NH}_{3}\right)_{6}\right]^{3+} /\left[\mathrm{Fe}(\mathrm{CN})_{6}\right]^{3-}$ system), a few other added features also attributed to this sensitivity, such as (i) SPCE/Au-NPFe ${ }_{2} \mathrm{O}_{3} \mathrm{NC} / \mathrm{RNA}$-bound surface confined $\left[\mathrm{Ru}\left(\mathrm{NH}_{3}\right)_{6}\right]^{3+}$ could generate more intense CC signal compared to voltammetry where the electrostatic interaction is free of any duplex intercalation and (ii) the double layer charge and charge derived from the surface confined target miRNA can easily be differentiated from the redox charges in diffusion layers allowing more sensitive charge measurements.

\subsection{Assay Specificity}

To check the assay functionality and specificity, we performed our assay in the absence and presence of complementary or non-complementary target miRNAs. In the absence of target miR-107 (i.e., SPCE/Au-NPFe $\mathrm{O}_{3} \mathrm{NC}$ without miR-107, control), the total charge density for the $\left[\mathrm{Ru}\left(\mathrm{NH}_{3}\right)_{6}\right]^{3+} /\left[\mathrm{Fe}(\mathrm{CN})_{6}\right]^{3-}$ system was significantly higher than that of the SPCE/bare electrode ( 4.5 vs $18.1 \mu \mathrm{Ccm}^{-2}$ ) (Fig. S3 vs Fig. 3). This charge density for the $\left[\mathrm{Ru}\left(\mathrm{NH}_{3}\right)_{6}\right]^{3+}$ system was $7.5 \mu \mathrm{Ccm}^{-2}$ (Fig. S3, supplementary materials). This is probably due to the presence of a low amount of $\left[\mathrm{Ru}\left(\mathrm{NH}_{3}\right)_{6}\right]^{3+}$ on the control electrode via nonspecific adsorption. In the case of the two non-complementary synthetic miRNAs (miR-21 and miR338-3p), as expected, using the same starting concentration (10 pM), the total charge 
densities obtained for the miR-21 and miR- 338-3p was found to be 16.1 and $17.3 \mu \mathrm{Ccm}^{-2}$ respectively (Fig. 3). These values for the $\left[\mathrm{Ru}\left(\mathrm{NH}_{3}\right)_{6}\right]^{3+}$ system was 6.0 and $7.3 \mu \mathrm{Ccm}^{-2}$ respectively (Fig. S3). Notably, the CC responses obtained with the non-complementary targets for the $\left[\mathrm{Ru}\left(\mathrm{NH}_{3}\right)_{6}\right]^{3+} /\left[\mathrm{Fe}(\mathrm{CN})_{6}\right]^{3-}$ system were similar to that obtained from the control response. A similar trend was obtained for the $\left[\mathrm{Ru}\left(\mathrm{NH}_{3}\right)_{6}\right]^{3+}$ system (Fig. S3, supplementary materials). This shows that the assay is not affected by the nonspecific response from similar size miRNAs. However, when compared to the total charge derived from non-specific targets and controls, the CC response from the target miR-107 was increased about 4-fold ( $82 \mu \mathrm{C}$ $\mathrm{cm}^{-2}$ ) (Fig. 3). This enhancement was about 2.5-fold for the $\left[\mathrm{Ru}\left(\mathrm{NH}_{3}\right)_{6}\right]^{3+}$ system (Fig. S3). These results clearly demonstrate the high specificity of our assay. The specificity of our developed assay is also comparable to several recently reported high-performance biosensors (Koo et al., 2016b; Liao et al., 2017; Wang et al., 2014).

\subsection{Assay Sensitivity}

To evaluate the assay sensitivity, a series of designated concentration of synthetic miR-107 ranging from 100 aM to $1.0 \mathrm{nM}$ were detected by our assay. As shown in Fig. 4, the CC response generated by $\left[\mathrm{Ru}\left(\mathrm{NH}_{3}\right)_{6}\right]^{3+} /\left[\mathrm{Fe}(\mathrm{CN})_{6}\right]^{3-}$ system increased with the increasing concentration of the target miRNA. This can be explained by the fact that, an increasing amount of miR-107 on the SPCE/Au-NPFe ${ }_{2} \mathrm{O}_{3} \mathrm{NC}$ electrode surface will have more anionic phosphate groups which in turn binds with more cationic $\left[\mathrm{Ru}\left(\mathrm{NH}_{3}\right)_{6}\right]^{3+}$. Thus more $\left[\mathrm{Ru}\left(\mathrm{NH}_{3}\right)_{6}\right]^{3+}$ will be electrocatalytically reduced to further catalyse the reduction of $\left[\mathrm{Fe}(\mathrm{CN})_{6}\right]^{3-}$ in the diffusion layer, thereby resulting enhanced CC response. The linear regression equation of the assay was estimated to be $\mathrm{y}\left(\right.$ charge density, $\left.\mu \mathrm{Ccm}^{-2}\right)=10.85$ (amount of miR-107) +3.1638 , with a correlation coefficient $\left(R^{2}\right)$ of 0.9984 . The limit of detection (LOD) was estimated to be $100 \mathrm{aM}$ and the response is clearly distinguishable from 
that of control and bare electrodes. It is important to mention that without the use of catalytic cycle step (only with the $\left[\mathrm{Ru}\left(\mathrm{NH}_{3}\right)_{6}\right]^{3+}$ system), we achieved a detection limit of $100 \mathrm{fM}$ (100 aM versus $100 \mathrm{fM}$ ), which is thousand-times less sensitive than that of the $\left[\mathrm{Ru}\left(\mathrm{NH}_{3}\right)_{6}\right]^{3+} /\left[\mathrm{Fe}(\mathrm{CN})_{6}\right]^{3-}$ system (see Fig. S6).

The LOD of our method is superior or comparable with those of existing miRNA electrochemical assays (Koo et al., 2016b; Pang et al., 2016; Yao et al., 2014). For example, the LOD of our method is approximately 1,000 times better than a recent choronoloumetric detection method reported by Yao et al. (2014). In addition to the superior sensitivity, our assay is relatively inexpensive (enzyme free, low-cost synthesis of $\mathrm{Au}-\mathrm{NPFe}_{2} \mathrm{O}_{3} \mathrm{NC}$ ) and simple (via adopting direct RNA adsorption and electrocatalytic signal amplification) whereas the method developed by Yao et al. relies on the enzyme based rolling-circle amplification process. Our approach has also obtained 100-folds better sensitivity than the voltammetric method reported by Koo et al (2017b). Moreover, while the voltammetric method requires the target (RNA) modification (i.e., polyadenylation) using Poly-A enzyme, our approach offers relatively simple (avoids pre-modification of target RNAs) and inexpensive (avoids costly enzymes) assay platform. A comparison of the LOD of our method with that of several other existing electrochemical methods reported in the last five years has been provided in Table S2 of supplementary materials.

\subsection{Analysis of miR-107 in Patient Derived Cell Lines and Tissues}

To determine whether our assay could be applied to real biological samples, we tested our method in total RNA sample extracted from human ESCC cell lines (HKESC-1 and HKESC-4) and one non-neoplastic oesophageal mucosa sample (as a control). As shown in Fig. 5A and $\mathrm{B}$, the corresponding bar diagram for $Q_{\mathrm{RNA}}$ and typical CC curve demonstrated that the CC response obtained with cancer cells from HKESC-1 and HKESC-4 was 
significantly higher than that of normal (70 and 54 vs $19 \mu \mathrm{Ccm}^{-2}$ ) suggesting the overexpression of miR-107. We then validated our assay performance in cancer cells with a RT-qPCR. As seen in Fig. 5C, the expression fold change data of a RT-qPCR strongly supports our findings (Fig. 5C vs Fig. 5A).

To further demonstrate the potential clinical applications, we extended our method to analyse miR-107 from the total RNA extracted from cancer tissues with their matched noncancer tissues from 4 patients. As indicated in Fig. 6A and B, all eight total RNA samples (including non-cancer tissue RNA; N1-N4 and cancer tissue RNA; P1-P4) showed different levels of miR-107 expression. For example, CC charge density obtained for P1 (T) was almost doubled when compared to the matched non-cancer P1(N) (67 vs $24 \mu \mathrm{Ccm}^{-2}$ ). A similar trend was obtained for the other patients samples where CC response derived from cancer samples (P2-P4) had significantly higher charge densities compared to the nonneoplastic counterparts (N2-N4), suggesting an upregulation of miR-107 expression in the ESCC tissue samples. We then validated our assay performance with a standard RT-qPCR method which was in excellent agreement with our findings (Fig. 6A vs 6C). The reproducibility of our assay (relative standard deviation, $\% \operatorname{RSD}=<5 \%$, for $n=3$ ) in analysing clinical sample is also in acceptable range, which shows better (Bettazzi et al., 2013) or comparable (Bartosik et al., 2014; Hong et al., 2013; Koo et al., 2016b; Miao et al., 2016) reproducibility when compared to the recently reported miRNA electrochemical sensors. The level of the reproducibility, sensitivity and selectivity of our assay in analysing patient sample as well as the validation with RT-qPCR analysis indicates the enormous potential of our detection method for screening clinically relevant miRNAs. Also, this approach has future implications in profiling gene expressions and molecular pathways in patients with cancer and other chronic diseases. 


\subsection{Advantages of the Assay}

The assay offers an important progress towards the ultrasensitive detection of miRNA. First, utilization of highly porous structure of $\mathrm{Au}-\mathrm{NPFe}_{2} \mathrm{O}_{3} \mathrm{NC}$ significantly enhances the capture efficiency via loading vast amounts of RNA on the gold surfaces. Additionally, it offers the direct and fast electron transfer between the target and electrode surface attributing the high sensitivity of the assay. Second, unlike the traditional heterogeneous hybridization-based detection, our assay exploits magnetic nanoparticle-based intimate mixing, separation and purification of miRNA which reduce the matrix effects of the biological samples. Thus, the method is less susceptible to non-specific detection. Third, the direct adsorption of target miRNA on an $\mathrm{Au}-\mathrm{NPFe}_{2} \mathrm{O}_{3} \mathrm{NC}$-modified electrode rather than the conventional RNA biosensing approach of using recognition and transduction layers, substantially simplifies the detection method by avoiding the complex chemistries underlying each step of the sensor fabrication. Fourth, RuHex bound electrostatically with the target, thereby avoiding the need of expensive electrochemical tags or labelling. Finally, electrochemical detection can complement with the miniaturized and multiplexed analysis in non-laboratory settings with high translational potential.

\section{Conclusions}

In conclusion, we have developed a sensitive electrochemical method for detecting small non-coding RNA (miRNAs) using multiple electrocatalytic signal amplification steps. Magnetically separated and purified target miRNA was directly adsorbed on novel Au$\mathrm{NPFe}_{2} \mathrm{O}_{3} \mathrm{NC}$ nanocomposites with high electrocatalytic activity. Further chronocoulometric charge interrogation of surface-bound RuHex (via interaction between $\left[\mathrm{Ru}\left(\mathrm{NH}_{3}\right)_{6}\right]^{3+}$ and miR-107 adsorbed onto the SPCE/Au- $\left.\mathrm{NPFe}_{2} \mathrm{O}_{3} \mathrm{NC}\right)$ coupled with the $\left[\mathrm{Fe}(\mathrm{CN})_{6}\right]^{3-/ 4-}$ system result in a significant signal enhancement via electrocatalytic cycle. The assay enabled the 
ultra-low level of limit of detection of $100 \mathrm{aM}$ and showed high reproducibility (\% RSD $=<5 \%$, for $n=3$ ) and specificity towards detecting a known oncogenic miRNA, miR-107, in

cell lines and tissue samples collected from patients with ESCC. This application of our assay on both in vitro and in vivo based clinical samples suggests the future use of screening any biomarkers including miRNAs (depending on the selection of specific capture probe). Considering the versatility of our assay, we believe that with further optimisation, this new strategy based on nanocomposite and electrocatalytic cycle can potentially be applicable for the determination of a wide variety of clinically relevant DNA or RNA biomarkers for other human cancers and chronic diseases.

\section{Acknowledgements}

This work was supported by the NHMRC CDF (APP1088966 to M.J.A.S.) and higher degree research scholarships to M.N.I. and M.K.M. from the Griffith University and University of Wollongong respectively. Y.Y and Z.A.A. are grateful to the Deanship of Scientific Research, King Saud University for funding through Vice Deanship of Scientific Research Chairs.

\section{Appendix A. Supplementary materials}

Supplementary materials associated with this article can be found in the online version at 10.1016/j.bios.2017.09.027. 


\section{References}

Bartosik, M., Hrstka, R., Palecek, E., Vojtesek, B., 2014. Anal. Chim. Acta 813, 35-40.

Bettazzi, F., Hamid-Asl, E., Esposito, C.L., Quintavalle, C., Formisano, N., Laschi, S., Catuogno, S., Iaboni, M., Marrazza, G., Mascini, M., Cerchia, L., De Franciscis, V., Condorelli, G., Palchetti, I., 2013. Anal. Bioanal. Chem. 405, 1025-1034.

Boon, E.M., Ceres, D.M., Drummond, T.G., Hill, M.G., Barton, J.K., 2000. Nat. Biotechnol. 18, 1096-1100.

Cheung, L.C., Tang, J.C., Lee, P.Y., Hu, L., Guan, X.Y., Tang, W.K., Srivastava, G., Wong, J., Luk, J.M., Law, S., 2007. Cancer Genet. Cytogenet. 178, 17-25.

Dong, H., Lei, J., Ding, L., Wen, Y., Ju, H., Zhang, X., 2013. Chem. Rev. 113, 6207-6233.

Fang, C.S., Kim, K.-s., Yu, B., Jon, S., Kim, M.-S., Yang, H., 2017. Anal. Chem. 89, 20242031.

Gao, Z., Yang, Z., 2006. Anal. Chem. 78, 1470-1477.

Haque, M.H., Gopalan, V., Yadav, S., Islam, M.N., Eftekhari, E., Li, Q., Carrascosa, L.G., Nguyen, N.-T., Lam, A.K., Shiddiky, M.J.A., 2017. Biosens. Bioelectron. 87, 615-621. 
Hayes, J., Peruzzi, P.P., Lawler, S., 2014. Trends Mol. Med. 20, 460-469.

Hong, C.-Y., Chen, X., Liu, T., Li, J., Yang, H.-H., Chen, J.-H., Chen, G.-N., 2013. Biosens. Bioelectron. 50, 132-136.

Hu, Y., Lam, K.Y., Wan, T.S., Fang, W., Ma, E.S., Chan, L.C., Srivastava, G., 2000. Cancer Genet. Cytogenet. 118, 112-120.

Islam, M.N., Masud, M.K., Haque, M.H., Hossain, M.S.A., Yamauchi, Y., Nguyen, N.-T., Shiddiky, M.J.A., 2017a. Small Methods, 1, 1700131, DOI: 10.1002/smtd.201700131 Islam, M.N., Gopalan, V., Haque, M.H., Masud, M.K., Hossain, M.S.A., Yamauchi, Y., Nguyen, N.-T., Lam, A.K.-Y., Shiddiky, M.J.A., 2017b. Biosens. Bioelectron. 98, 227233.

Johnson, B.N., Mutharasan, R., 2014. Analyst 139, 1576-1588.

Masud, M.K., Islam, M.N., Haque, M.H., Tanaka, S., Gopalan, V., Alici, G., Nguyen, N.-T., Lam, A.K., Hossain, M.S.A., Yamauchi, Y., Shiddiky, M.J.A., 2017. Chem. Commun. 53, 8231-8234.

Kelley, S.O., Boon, E.M., Barton, J.K., Jackson, N.M., Hill, M.G., 1999. Nucleic Acids Res. 27, 4830-4837.

Koo, K.M., Carrascosa, L.G., Shiddiky, M.J.A., Trau, M., 2016a. Anal. Chem. 88, 67816788.

Koo, K.M., Carrascosa, L.G., Shiddiky, M.J.A., Trau, M., 2016b. Anal. Chem. 88, 20002005.

Koo, K.M., Sina, A.A.I., Carrascosa, L.G., Shiddiky, M.J.A., Trau, M., 2015. Anal. Methods 7, 7042-7054.

Labib, M., Berezovski, M.V., 2015. Biosens. Bioelectron. 68, 83-94.

Labib, M., Sargent, E.H., Kelley, S.O., 2016. Chem. Rev. 116, 9001-9090.

Lapierre, M.A., O'Keefe, M., Taft, B.J., Kelley, S.O., 2003. Anal. Chem. 75, 6327-6333. 
Liao, T., Li, X., Tong, Q., Zou, K., Zhang, H., Tang, L., Sun, Z., Zhang, G.-J., 2017. Anal. Chem. 89, 5511-5518.

Liu, L., Xia, N., Liu, H., Kang, X., Liu, X., Xue, C., He, X., 2014. Biosens. Bioelectron. 53, 399-405.

Mestdagh, P., Hartmann, N., Baeriswyl, L., Andreasen, D., Bernard, N., Chen, C., Cheo, D., D'Andrade, P., DeMayo, M., Dennis, L., Derveaux, S., Feng, Y., Fulmer-Smentek, S., Gerstmayer, B., Gouffon, J., Grimley, C., Lader, E., Lee, K.Y., Luo, S., Mouritzen, P., Narayanan, A., Patel, S., Peiffer, S., Ruberg, S., Schroth, G., Schuster, D., Shaffer, J.M., Shelton, E.J., Silveria, S., Ulmanella, U., Veeramachaneni, V., Staedtler, F., Peters, T., Guettouche, T., Wong, L., Vandesompele, J., 2014. Nat. Methods 11, 809815.

Miao, X., Wang, W., Kang, T., Liu, J., Shiu, K.-K., Leung, C.-H., Ma, D.-L., 2016. Biosens. Bioelectron. 86, 454-458.

Pang, Y., Wang, C., Wang, J., Sun, Z., Xiao, R., Wang, S., 2016. Biosens. Bioelectron. 79, 574-580.

Park, S., Singh, A., Kim, S., Yang, H., 2014. Anal.Chem. 86, 1560-1566.

Patnaik, S.K., Mallick, R., Yendamuri, S., 2010. J. Gastrointest. Oncol. 1, 55-63.

Peng, Y., Jiang, J., Yu, R., 2014. Anal. Methods 6, 2889-2893.

Pritchard, C.C., Cheng, H.H., Tewari, M., 2012. Nat. Rev. Genet. 13, 358-369.

Sharma, P., Saraya, A., Gupta, P., Sharma, R., 2013. Biomarkers 18, 322-330.

Shiddiky, M.J.A., Torriero, A.A., Reyna-Gonzalez, J.M., Bond, A.M., 2010. Anal. Chem. 82, 1680-1691.

Shiddiky, M.J.A., Torriero, A.A., Zhao, C., Burgar, I., Kennedy, G., Bond, A.M., 2009. J. Am. Chem. Soc. 131, 7976-7989. 
Sina, A.A., Carrascosa, L.G., Palanisamy, R., Rauf, S., Shiddiky, M.J.A., Trau, M., 2014a. Anal. Chem. 86, 10179-10185.

Sina, A.A., Howell, S., Carrascosa, L.G., Rauf, S., Shiddiky, M.J.A., Trau, M., 2014b. Chem Commun. 50, 13153-13156.

Steel, A.B., Herne, T.M., Tarlov, M.J., 1998. Anal. Chem. 70, 4670-4677.

Wang, K., Zhang, K., Lv, Z., Zhu, X., Zhu, L., Zhou, F., 2014. Biosens. Bioelectron. 57, 9195.

Xia, N., Zhang, L., Wang, G., Feng, Q., Liu, L., 2013. Biosens. Bioelectron. 47, 461-466.

Xia, N., Zhang, Y., Wei, X., Huang, Y., Liu, L., 2015. Anal. Chim. Acta 878, 95-101.

Yadav, S., Masud, M.K., Islam, M.N., Gopalan, V., Lam, A.K., Tanaka, S., Nguyen, N.-T., Hossain, M.S., Li, C., Yamauchi, Y., Shiddiky, M.J.A., 2017. Nanoscale 9, 8805-8814.

Yao, B., Liu, Y., Tabata, M., Zhu, H., Miyahara, Y., 2014. Chem. Commun. 50, 9704-9706.

Zhang, J., Song, S., Zhang, L., Wang, L., Wu, H., Pan, D., Fan, C., 2006. J. Am. Chem. Soc. 128, 8575-8580.

Zhang, J., Wang, L., Pan, D., Song, S., Fan, C., 2007. Chem. Commun. 11, 1154-1156. 


\section{Figure captions}

Fig. 1. Schematic overview of the assay. Target miRNA was first magnetically isolated and purified from the RNA sample pool and adsorbed directly on the $\mathrm{Au}-\mathrm{NPFe}_{2} \mathrm{O}_{3} \mathrm{NC}$ which was magnetically held on the SPCE electrode. The $\left[\mathrm{Ru}\left(\mathrm{NH}_{3}\right)_{6}\right]^{3+}$ was electrostatically attached with the surface bound negatively charged miRNAs. The detection was achieved by the chronocoulometric charge interrogation of $\left[\mathrm{Ru}\left(\mathrm{NH}_{3}\right)_{6}\right]^{3+} /\left[\mathrm{Fe}(\mathrm{CN})_{6}\right]^{3-}$ electrocatalytic cycle.

Fig. 2. Charge density obtained for the $10 \mathrm{pM}$ synthetic miR-107 at the SPCE/ $\mathrm{NPFe}_{2} \mathrm{O}_{3} \mathrm{NC}$, SPCE/Au-NPFe ${ }_{2} \mathrm{O}_{3} \mathrm{NC}$ (with and without electrocatalytic cycle) electrodes. Total charge, $\mathrm{Q}=$ Faradaic + non-Faradaic charges of the system. Inset, corresponding CC curves $\left(Q\right.$ vs $\left.t^{1 / 2}\right)$. Each data point represents the average of three independent trials, and error bars represent the standard deviation of measurements $(\% \mathrm{RSD}=<5 \%$, for $\mathrm{n}=3)$.

Fig. 3. Assay specificity. Charge density obtained for the synthetic miR-107 at designated electrodes in the presence of $\left[\mathrm{Ru}\left(\mathrm{NH}_{3}\right)_{6}\right]^{3+} /\left[\mathrm{Fe}(\mathrm{CN})_{6}\right]^{3-}$ electrocatalytic cycle. Left bar 
represents the charge density obtained at the bare SPCE after adsorbing $10 \mathrm{pM}$ of target miR107. Control and Target-miRNA bars represent the charge density obtained at SPCE/Au$\mathrm{NPFe}_{2} \mathrm{O}_{3} \mathrm{NC}$ electrode before and after adsorbing $10 \mathrm{pM}$ of target miR-107. miR-21 and miR338-3p bars represent the charge density obtained at SPCE/Au-NPFe $\mathrm{O}_{3} \mathrm{NC}$ electrode after adsorbing $10 \mathrm{pM}$ of non-complimentary miR-21 and miR-338-3p targets respectively. Inset, corresponding CC curves ( $Q$ vs. $t^{1 / 2}$ ). Each data point represents the average of three independent trials, and error bars represent the standard deviation of measurements (\% RSD $=<5 \%$, for $n=3)$.

Fig. 4. Assay sensitivity. (A) Typical CC curves ( $Q$ vs. $t^{1 / 2}$ ) for the (b-i); $100 \mathrm{aM}-1.0 \mathrm{nM}$ of miR-107. Curves a is for the charge density obtained at SPCE/Au-NPFe ${ }_{2} \mathrm{O}_{3} \mathrm{NC}$ electrode before adsorbing target miR-107. (B) $Q_{\mathrm{RNA}}$-concentration profile for the range of $100 \mathrm{aM}$ to $1.0 \mathrm{nM}$ miR-107. Inset, corresponding calibration plot. The concentration of RuHex and ferricyanide is $50 \mu \mathrm{M}$ and $4.0 \mathrm{mM}$ respectively. Each data point represents the average of three independent trials, and error bars represent the standard deviation of measurements (\% $\mathrm{RSD}=<5 \%$, for $n=3)$.

Fig. 5. Analysis of cell lines. (A) Corresponding bar diagram for $Q_{\mathrm{RNA}}$ obtained with HKESC-1 and HKESC-4 cancer cell line. (B) Typical CC curves ( $Q$ vs. $t^{1 / 2}$ ) obtained with cell line samples. (C) RT-qPCR derived miR-107 expression profile (fold-change data) in cell lines. Each data point represents the average of three independent trials, and error bars represent the standard deviation of measurements (\% RSD $=<5 \%$, for $n=3$ ).

Fig. 6. Analysis of patient samples. (A) Corresponding $Q_{\mathrm{RNA}}$ obtained for four ESCC patients (P1-P4) (four tumor samples with matched non-cancer samples, T-N). (B) Typical 
CC curves ( $Q$ vs. $t^{1 / 2}$ ) obtained with patients' samples (C) RT-qPCR derived miR-107 expression profile (fold-change data) in patient samples. Each data point represents the average of three independent trials, and error bars represent the standard deviation of measurements ( $\%$ RSD $=<5 \%$, for $n=3)$. 


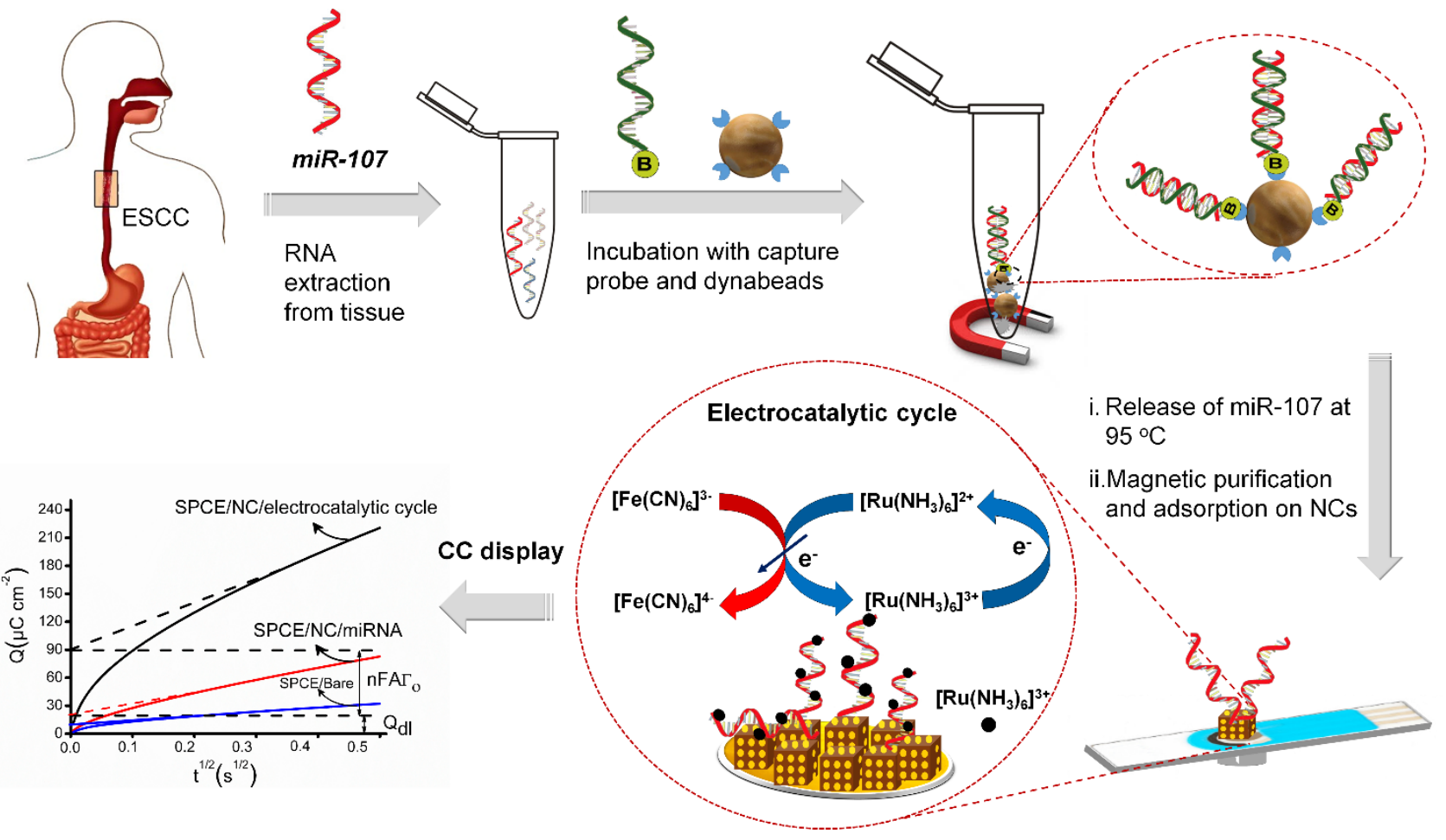

Fig. 1. 


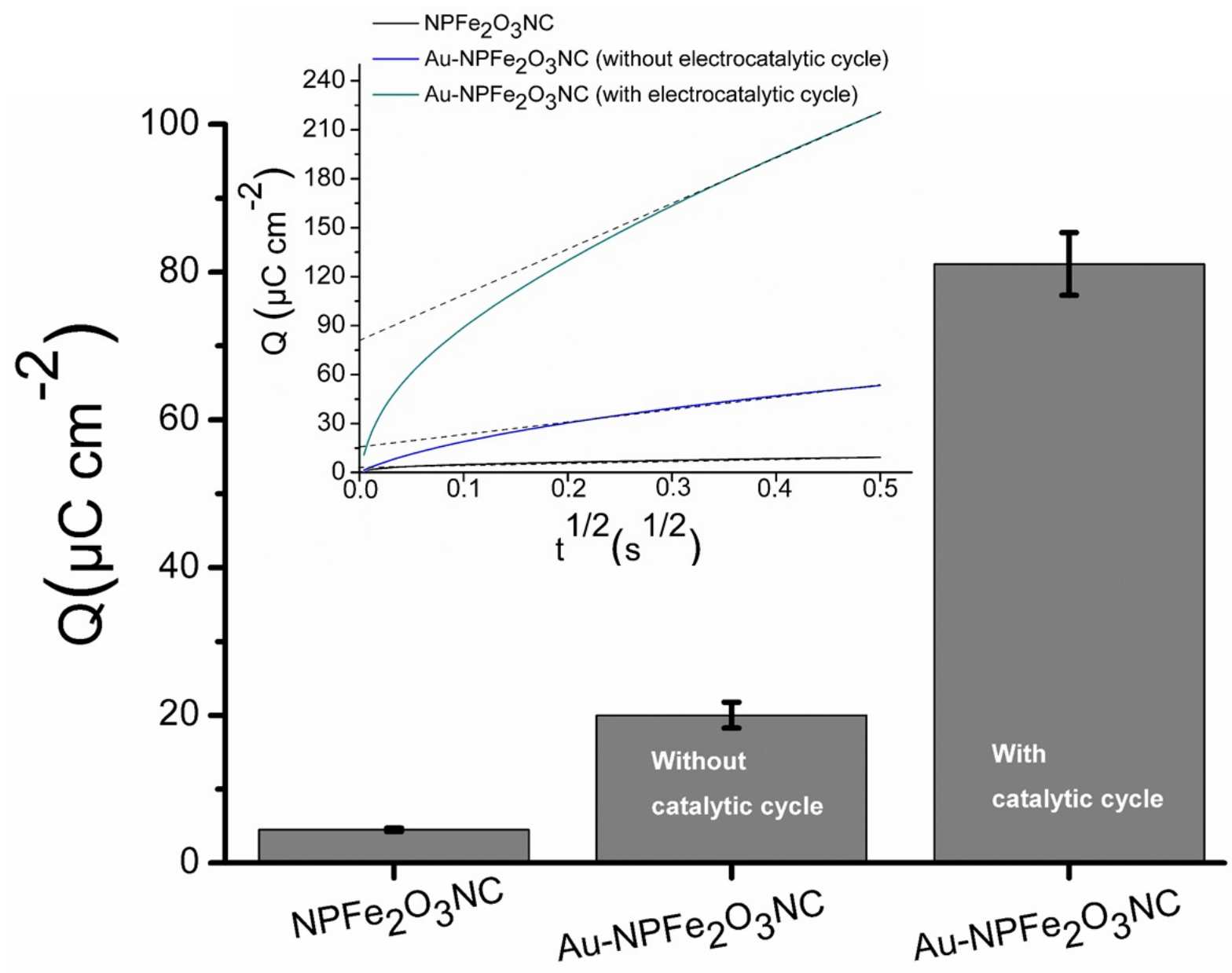

Fig. 2. 


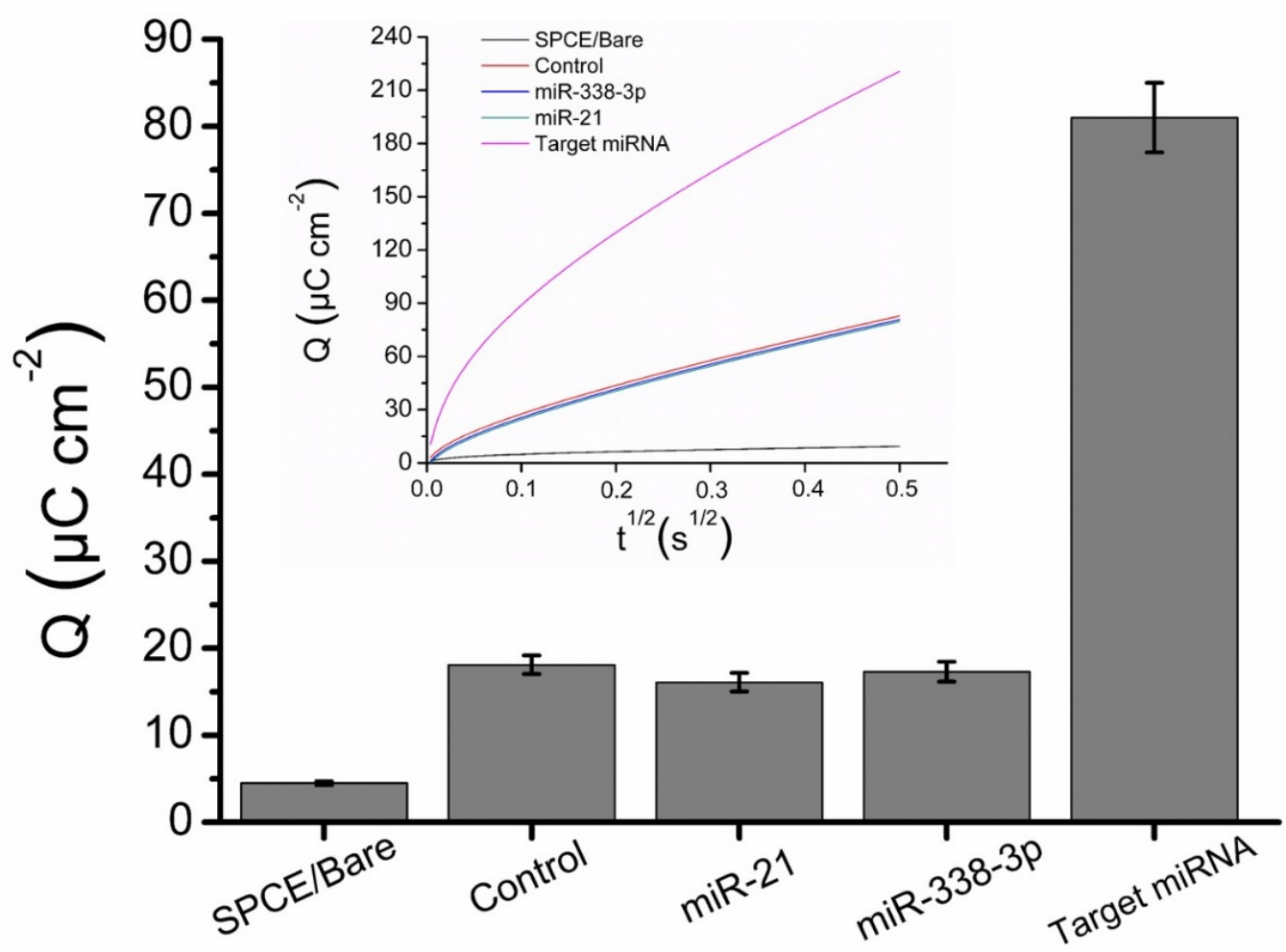

Fig. 3. 
A)

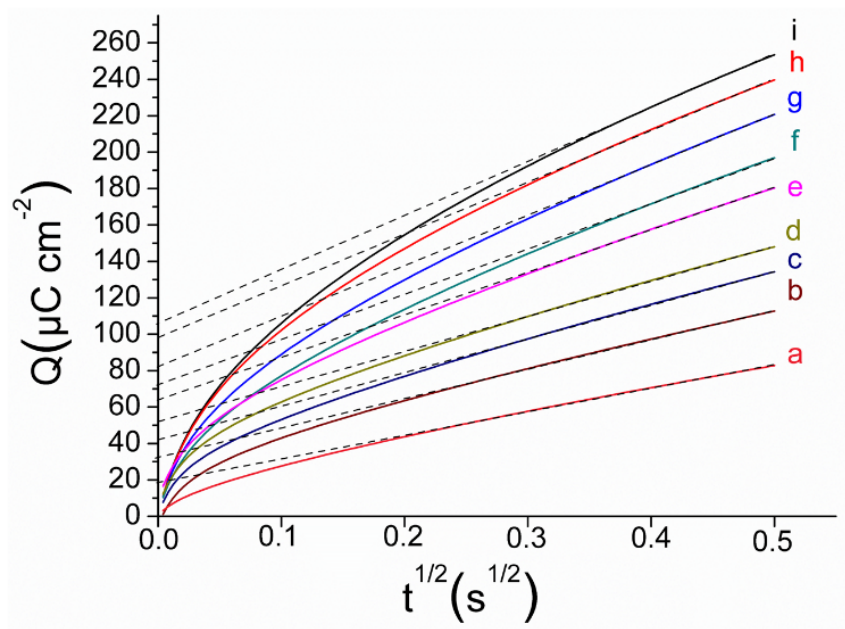

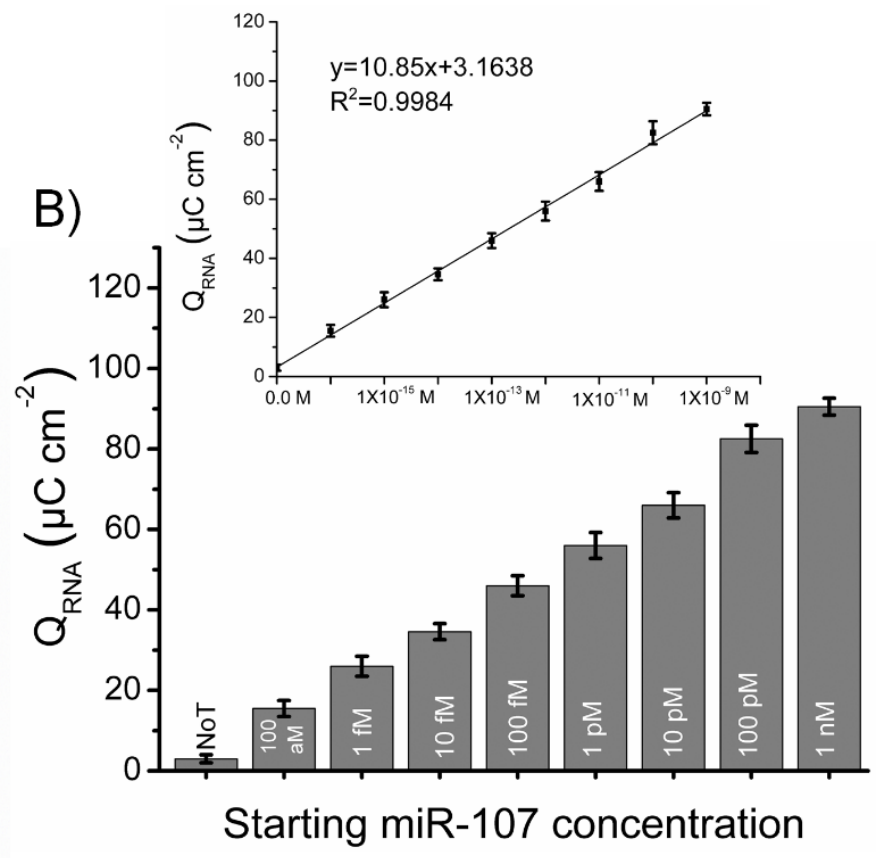

Fig. 4. 

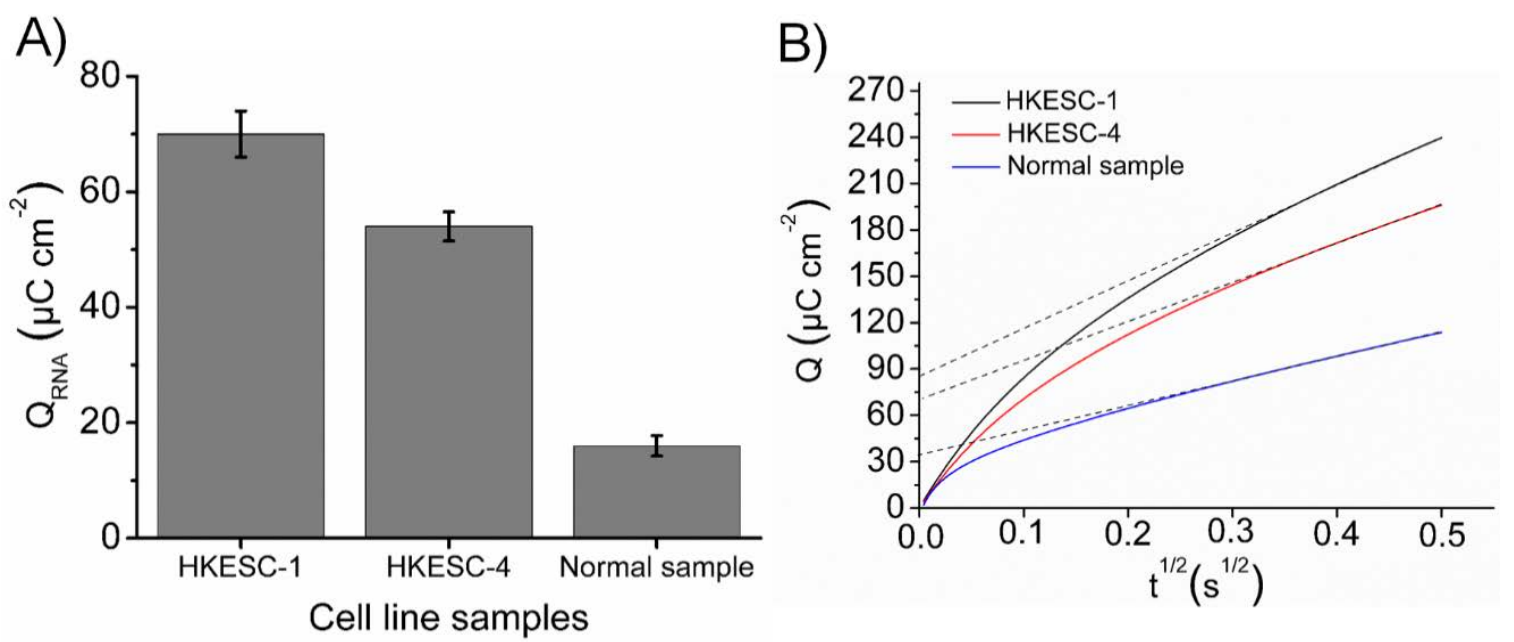

C)

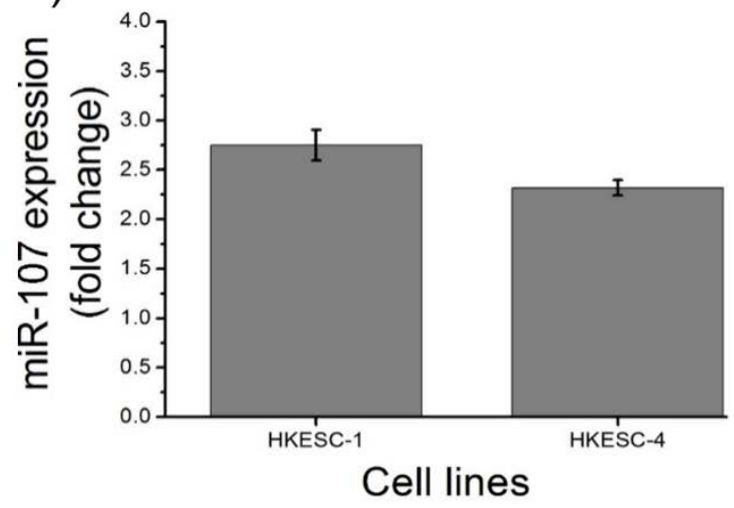

Fig. 5. 


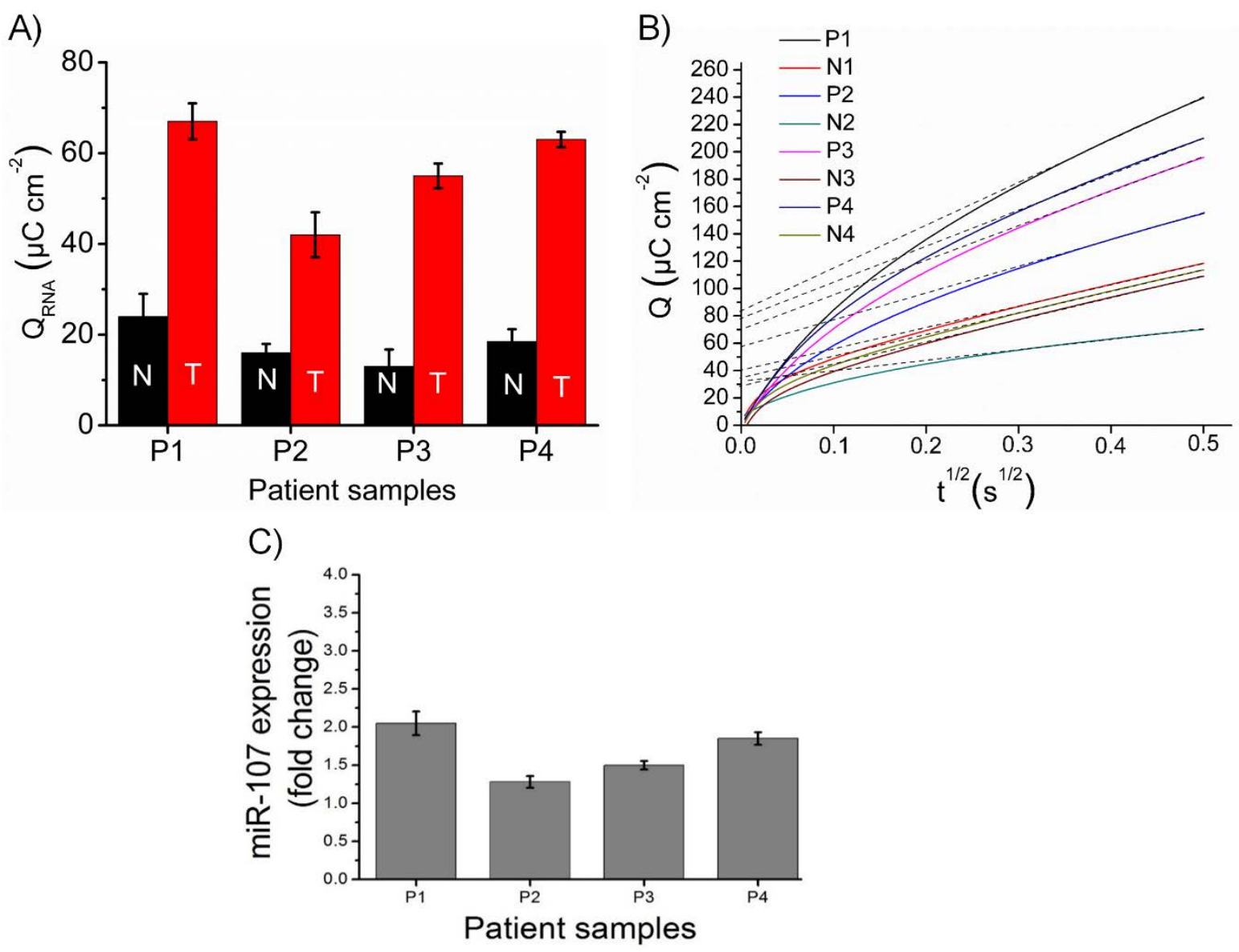

Fig. 6. 